\title{
THE INCOME BASE OF DISTRICT TOWNS IN THE SLOVAK REPUBLIC
}

\author{
Viktória Bobáková \\ Full Professor, PhD; \\ Pavol Jozef Šafárik University in Košice, Faculty of Public Administration, \\ Department of Economics and Management of Public Administration \\ Address: 66 Popradská, 04001 Košice, Slovak Republic. \\ E-mail: viktoria.bobakova@upjs.sk
}

\section{Lucia Rožová}

PhDr., Student of the 3rd level of higher education,

Pavol Jozef Šafárik University in Košice, Faculty of Public Administration, Department of Economics and Management of Public Administration Address: 66 Popradská, 04001 Košice, Slovak Republic.

E-mail: lucia.rozova@student.upjs.sk

\section{Abstract}

The primary self-governing unit of the local self-governing body in the Slovak Republic is a municipality. Its fundamental role is to take care of the comprehensive development of the municipal territory and the needs of its inhabitants. Currently, there are 2,890 municipalities in Slovakia, of which 140 are towns. Since these towns/cities play an increasingly important role in the economic, social and cultural development of the state, we deal with the evaluation of the economic results of the district towns in our article. We define the assumption that the level of financial self-sufficiency is influenced by the level of economic maturity of the territory where the city is located. The research findings suggest that the indicator of financial independency achieves the highest values in those towns located within the territories of Western and Central Slovakia, thus, in the most economically advanced areas of the country. The towns located within these areas are more populated because of better employment opportunities and low unemployment rates. The fiscal decentralization assumed an increase of own tax revenues of local self-government, however, the goal has only partially been fulfilled. The most significant item of tax revenue is personal income tax, which is the only one with the character of a share tax. The redistribution amount and criteria of this tax are beyond the power of the towns, although the revenues from this tax are included in their own tax revenues. Since there are considerable differences in the eco- 
nomic levels of parts of the country and there are changes in the demographic structure and natural conditions, there is a need to re-assess the redistribution criteria of this tax into the budgets of the towns in Slovakia. We assume that this will result in a reduction of the differences in the scope and quality of provision of public services provided by these towns.

Keywords: fiscal decentralisation; local government; competence of local government; share tax; financial management of local government; local government revenues; local government tax revenues; fiscal determination of tax revenue; financial autonomy; financial self-sufficiency.

Citation: Bobáková, V. \& Rožová, L. (2019). The Income Base of District Towns in the Slovak Republic. Public Administration Issue, no 6, (Special Issue II, electronic edition), pp. 121-134 (in English); DOI: 10.17323/1999-5431-2019-0-6-121-134.

\section{Introduction}

The formation of territorial self-government in the Slovak Republic has undergone a lengthy development which has been influenced by many political and social events. The processes and reforms that have led to the greater autonomy of municipalities and regions have been part of the process of political, economic, social and cultural renewal of territorial communities. As with several other European countries, the principle of self-government is also constitutionally enshrined in Slovakia.

In the SR, a decentralised model of state organisation with the existence of territorial self-government is applied. The division of powers between the central government and lower levels increases the quality of services provided. Several analyses (Bird, 2003; Youngman, 2016; Ermini, 2009; Sungurov \& Tiniakov, 2018) confirm that if citizens have sufficient influence on the quality, structure and scope of the services provided by the public sector, they are more willing to contribute to the financial and material resources in favour of their provision. This willingness is mainly due to the fact that they can directly monitor their use. According to Johnson and Minis (1996, p. 5), decentralisation is a primary strategy for transferring central government competence to lower-level governments. This is a fundamental change in the institutional framework in which political, social and economic decisions are made.

Decentralisation also has many critics. One important argument against decentralisation is that there is not enough empirical evidence of a positive relationship between decentralisation and poverty eradication. Decentralised structures claim that the negative can be neutralised by a fair financial compensation system. The argument that is also used against decentralisation is that it reduces the efficiency of public spending, especially in small municipalities, by increasing the number of management levels, elected bodies and officials. As a counterargument, it can be stated that decentralisation can lead to better use of the local potential as well as to democratic benefits (better response to the needs and 
requirements of local people). However, there are many more arguments against as well as for decentralisation.

As a consequence of decentralisation efforts, local government undoubtedly deserves to be labelled as one of the most important foundations and an integral part of a democratic society. Self-government cannot be seen only as a legal term. Its social, cultural and economic dimension is also important (Daňková et al., 2017). In a broader context, territorial self-government forms a democratic basis for organising and managing public affairs under the conditions of modern democracies, where particular emphasis is placed on the application of the principles of decentralisation and subsidiarity (Nižňanský \& Hamalová, 2013).

Public sector financial theory emphasises that decision-making processes should be carried out at the lowest possible level of the community (if these are the roles of the public sector then at the lowest level of the public administration). The reason for this is that the important private-public relations take place at the local level.

Many factors influence the role and possibilities of public administration to support development at local and regional levels. These are economic, legal, social, cultural and political factors. An important factor is the possibility of financing activities in the territory. Regional development at the level of local selfgovernment is focused primarily on development activities that can be performed in terms of their competences.

\section{The Aim, the Material and the Methods}

The development of towns and cities is related to the possibilities, focus and abilities of individual persons involved at the local, regional, but also central level of public administration. The development potential of the respective territories is largely influenced by the structure and character of the settlement structure (Kaderábková \& Peková, 2012). In terms of the efficiency of meeting the needs and spending of public resources, the structure and level of population concentration in individual settlements plays an important role. The thriving and dynamic small and medium-sized cities (within the European understanding) can play an important role, not only in terms of the welfare of their own populations but also that of the inhabitants of the surrounding countryside. Major production and consumption activities are concentrated in cities. They are considered to be critically important in generating and applying innovations used in a variety of ways in social and economic life.

The crucial challenge is therefore to create the conditions for a sustainable local economy. The vast majority of Slovakia's population live in small or mediumsized settlements, which is a consequence of the specific development of Slovakia's settlement structure. Currently, more than $50 \%$ of the Slovakian population live in towns and in 2050 this figure is likely to increase to $65 \%$. Slovakia, therefore, needs a strong local government, flexibly responding to changing conditions. We evaluated district towns because district cities are the economic, political and cultural centres of the region. 
According to the administrative-management division, the SR is divided into 8 regions and 79 districts. The subject of our research is 68 district cities. Due to the lack of published information regarding financial management and the unavailability of final accounts and annual financial reports, three district towns were excluded from the sample material. In addition, the two largest Slovak cities, Košice and Bratislava, are officially divided into several districts, Košice I-IV, Košice surroundings and Bratislava I-V. The three districts were listed together under the one for improved transparency. Subsequently, district cities were divided into three areas (Western, Central and Eastern Slovakia). The reference period was 2013-2017.

The aim of the paper is to evaluate the results of financial management in the conditions of district towns of the Slovak Republic. The main focus was on the income of these cities, with an emphasis on tax sharing, which in the Slovak Republic is personal income tax. Based on the content analysis of final accounts and annual financial reports of selected district towns, data were collected for individual items of the income part of their budgets in the initial phase, then ratio indicators were selected and calculated, and finally the average values of selected income items for all monitored districts together and for the three selected areas as well. For evaluation, we used the indicator of the tax sharing yield per capita, the share of the tax sharing revenues on the tax revenues of the cities, and the indicator of financial self-sufficiency. Financial self-sufficiency is an indicator expressing the degree of autonomy and stability of local government management.

We have focused our attention on financial self-sufficiency for several reasons. The first reason is that the local government has considerable public resources. It collects $70 \%$ of the personal income tax and also has the ability to determine its own local taxes.

The second reason is that the local priorities are financed from the local budgets. Into the local budgets are also reflected opportunities, threats and risks to which these are exposed. Their analysis enables an assessment and comparison of the real degree of the local government position within the country and on an international level. Another reason for focusing on financial self-sufficiency is that there is a close relationship between the financial possibilities of selfgovernment and their impact on the quality of life, living standards and local development. By exploring financial self-sufficiency, we can identify and understand specific local issues.

The ways of measuring financial self-sufficiency are different and take into account different approaches to defining financial self-sufficiency. In terms of research, we can choose a narrower or very broad approach. In the presented study, we chose a relatively narrow approach. We evaluated the financial selfsufficiency of this group of cities by comparing a share of their own income to the total income.

When creating maps, showing the development of selected indicators, the method of cartography was chosen, the size of which depicts the resulting values of district towns for individually selected ratio indicators. The results represent averaged values over the entire five-year review period. 


\section{The tax base of the cities}

There are two levels in Slovakia's local government: local and regional level. Each of these levels has their own degree of reach, competence, responsibility, and the powers they have acquired in the process of decentralisation. There is a compensatory relationship between the expected benefits of decentralisation and its costs. Boadway (2001) states that the benefits of decentralisation can only be realised when at the same time potentially sacrificing some efficiency and equity. The extent to which these sacrifices will be implemented depends heavily on further steps that go along with decentralisation.

Financial decentralisation, implemented in 2005, enabled territorial self-government units to better influence the revenue side of their budgets. The distribution of funds between the different levels of government can be characterised by transparency in resource allocation, predictability of its volume for decentralised levels of government and some autonomy of decentralised government levels in the acquisition and use of funds. Jílek (2008, p. 15) states that if local and regional authorities are to carry out decentralised functions effectively, they must have the power to:

a) collect adequate revenue, whether locally collected or provided by a higher level of government,

b) make decisions on expenditures.

Every governmental level, each self-government body has its own budget and is responsible for the management of it. Part of the financial decentralisation was through the Act on Budgetary Determination of Revenue from the Income Tax for Local Government. In accordance with this Act, the income of the municipal budget became a share of the individual income tax. The use of tax sharing is a result of applying a general principle - the principle of solidarity. The second regulation was the Local Tax Act itself, which allowed municipalities to collect local taxes as their own source of revenue. Municipalities in Slovakia have very limited tax jurisdiction. The individual municipalities have the most power within the defined legal rules only in their own local taxes. Municipalities can collect specific taxes from the enacted system of local taxes that they impose as a tax burden on their citizens, or even on other entities that reside in the territory of a given municipality or do business within this territory.

The prerequisite for creating a sufficient revenue base is that the revenue of the municipalities is designed to be profitable, to some extent dependent on the activity of the municipality and so that the municipality has the possibility to influence certain resources itself. At the same time, it is appropriate for the revenue to be evenly distributed over time in order to provide public goods of approximately the same quality and quantitatively in a certain timeframe, it should be relatively wellplanned and from the choice point of view not demanding on the administration.

District cities in Slovakia provide financing for self-government competences mainly from their own tax and non-tax revenues. From the state budget subsidies, from the relevant chapters of the state budget, the competences of the transferred state administration performance and other tasks related to regional development, environmental protection and the implementation of projects co-funded by the European Union are financed. 
Table 1

Income base of district towns in Slovakia

\begin{tabular}{|c|c|c|c|c|}
\hline & \multicolumn{3}{|c|}{ AVERAGE VALUES FOR YEARS 2013-2017 } & \multirow{4}{*}{$\begin{array}{c}\text { Average } \\
\text { values } \\
\text { for all } \\
\text { monitored } \\
\text { districts }\end{array}$} \\
\hline & Western Slovakia & Central Slovakia & Eastern Slovakia & \\
\hline Number of Districts & 26 & Slovakia & 19 & \\
\hline $\begin{array}{l}\text { Average no. } \\
\text { of Inhabitants }\end{array}$ & 43998 & 24585 & 37352 & \\
\hline Tax revenue & 17739488 & 9900331 & 14381233 & 13817710 \\
\hline $\begin{array}{l}\text { Revenue from } \\
\text { Tax Sharing }\end{array}$ & 11809772 & 7240386 & 10955863 & 9923979 \\
\hline Real Estate Tax & 3526432 & 1560012 & 2327559 & 2509763 \\
\hline $\begin{array}{l}\text { Goods and } \\
\text { Services Tax }\end{array}$ & 2370729 & 906461 & 1560116 & 1637760 \\
\hline Non-Tax Revenue & 3416360 & 1651353 & 2988661 & 1048947 \\
\hline Grants and transfers & 6881606 & 3856179 & 7224687 & 1957810 \\
\hline
\end{tabular}

Source: Authors' own processing of data based on the Final Accounts of the Public Sector in 2013-2017.

Based on the content analysis and recalculation of data from the final accounts and the annual reports of selected district towns in Slovakia, the average values of individual tax revenue items for all monitored districts as well as individual areas were quantified. The above table shows that the districts located in Western Slovakia achieved the highest tax revenues, non-tax revenues and grants and transfers. The lowest tax and non-tax revenues and grants and transfers were achieved by district towns in Central Slovakia.

The most significant item of the tax revenue is the individual income tax, which is the only one with the character of tax sharing. At the same time, in accordance with Act no. 583/2004 it is considered to be the local government units' own income. The yield of this tax was increasing over the review period. Better performance achieved is mainly due to the change in the distribution of tax revenue for municipalities, as well as an improvement in the success of their collection and a faster-growing labour market in comparison with the official estimates. From 1st Jan 2016, with the amendment to the Act on Budgetary Determination of Revenue from the Income Tax for Local Government, the percentage of income on individual income tax for municipalities increased from $68.5 \%$ (2015) to $70 \%$. Until that date, the State was also the recipient of the income tax. Since 2016, the yield has been redistributed to territorial self-governing units only (municipalities and self-governing regions).

The second most important item is the real estate tax, which is also a local tax, but in the final accounts this type of revenue is entered outside of this category. The real estate tax is regulated by Act no. 528/2004 Coll. on Local Taxes and the Fee for Municipal Waste and Small Construction Waste, as amended. The real estate tax consists of taxes on buildings, land and apartments and nonresidential premises. 
Local taxes are referred to in the summary tables as taxes on goods and services, or as the tax on specific services. In most districts, local taxes were levied, such as a dog tax, a tax on non-winning gaming machines, vending machines, and tax on public space use. An obligatory fee for municipal waste and small construction waste was collected in the territory of each monitored city, which was a significant item of the local taxes. It is also worth mentioning a new source of income for the local government, a development fee, which has also become a form of revenue for municipalities since 2016. It is, however, an optional financial instrument of the local government, so it is up to the municipality to decide whether to levy this charge in its territory or not. Predominantly the district towns of Western Slovakia decided to introduce this fee (Pezinok, Malacky, Senec). In particular, the amount of 353,560 EUR in financial resources in 2017 was taken in by Malacky through development tax.

\section{Tax Sharing - the most significant source of revenue}

Tax sharing represents a source of revenue for the municipal budget which is a result of the reform efforts to achieve greater efficiency within public administration. This type of revenue is intended to provide sufficient resources for territorial self-government. In doing so, the central government maintains control over the volume of funds. Tax sharing causes less autonomy of the local government in comparison with autonomous taxes. It can significantly influence the overall behaviour of the local governments by bringing tax revenues from the same sources as the income of all the public levels, which changes fiscal stimulus and financial policy outcomes. Their large yields are attractive to self-government, while the division itself avoids the many disadvantages of local taxation. Redistribution formulas are usually defined directly in tax sharing laws, fiscal balancing, etc.

The advantage of the redistribution of the shared tax, in our case the income tax of individual persons, is that it is a relatively inexpensive way of securing tax revenues for lower levels of self-government. On the other hand, a disadvantage is that local governments cannot set their own rates, i.e. it does not allow a link between decisions on revenue and expenditure, since the increase in expenditure in a particular municipality, the VÚC, does not have a direct impact on the tax amount in its territory. The disadvantage is that central governments tend to look at share taxes as their source of revenue and may try to regulate their use, just as with subsidies.

The method of distributing the revenue from individual income tax is governed by the Government Order no. 668/2004 Coll., On the Distribution of Income Tax Revenue of Territorial Self-Government. This regulation includes the following allocation criteria: population, village altitude, municipal size category, population over 62 years of age and number of pupils in school facilities. The criteria were created in relation to the original competences of the municipalities. Municipalities receive 1/12 of the total annual share tax each month. At present, the share of municipal governments in income tax revenues is $70 \%$. 
To date, municipalities' share of individual income tax revenue is determined as follows:

- $\quad 5 \%$ by the number of inhabitants within the municipality at the age of 62 ,

- $\quad 23 \%$ by the number of inhabitants with permanent residency in the municipality territory, out of which $57 \%$ is calculated by the coefficient of the village altitude,

- $\quad 32 \%$ by the number of inhabitants with permanent residency in the municipality territory adjusted by the size coefficient of the municipality,

- $\quad 40 \%$ by the number of pupils in primary art schools and school facilities.

The largest advantage of this tax category is the fact that municipalities are free to decide on their direction of use. Maruchnič and Čunderlík (2005) also define other benefits of municipal financing through individual income tax. These include, in particular, the transparency and accuracy of the funding system. Another argument in favour of the shared taxes is the fact that income tax is one of the most stable taxes and its collection is the most proportioned over the course of the year. Similarly, the growth rate of its revenue is linked to rising employment and real income. At the same time, a largely negative fact is that the municipalities learn about the amount of their share at the end of the calendar year when the state budget is approved for the following financial year. For this reason, local governments have greatly limited possibilities for the planning of their expenditure for the following year. Until 2016, the instability of the system of individual income tax distribution also caused a significant lack of participation by municipalities in central taxes. Constantly changing amounts of shares did not allow municipalities to predict the amount of shares in their budget.

Although each state territory has its own administrative structure, it is not a homogeneous environment. Individual territorial units have different economic, social and geographical characteristics. The criterion on the basis of which the income tax of individual persons is distributed among municipalities is the number of inhabitants of the municipality with permanent residence in the municipality as of 1st January of the previous calendar year. The criterion of the number of inhabitants represents the application of the principle of equality - individual municipalities receive the same amount of tax income per capita, regardless of the catchment area where they provide their original functions and without distinguishing the scope of provided services. At the same time, this has the character of income stability, while acting as a factor of financial balancing, and it supports the ability of municipalities to fund essential public services. A part of the yield (57\%) is calculated by the altitude coefficient of the village centre. On the basis of the coefficient laid down in the regulation, municipalities whose centre elevation exceeds $373 \mathrm{~m}$ (i.e. a coefficient higher than 1.00) receive a higher share of the tax revenue at the expense of lowersituated municipalities. In formulating this criterion, the legislator took into account the fact that municipalities are located in different geographical zones and that any increased energy requirements must be compensated for. Specific coefficients for each municipality are defined by government regulations.

To differentiate "energy demand", a more comprehensive indicator, taking into account local climate differences (long-term average air temperature, rainfall, wind speed, etc.) would be more appropriate. Altitude affects the differentiation of climatic elements, but only indirectly through the relief of the landscape. The altitude criterion seems to be a simplified criterion. 
Table 2

\section{Share of income tax of individual persons on tax revenues of district cities of Slovakia}

\begin{tabular}{|l|c|c|c|c|}
\hline & \multicolumn{2}{|c|}{ AVERAGE VALUES FOR YEARS 2013-2017 } & \multicolumn{2}{|c|}{$\begin{array}{c}\text { Average } \\
\text { values } \\
\text { for all }\end{array}$} \\
\hline & Western Slovakia & Central Slovakia & Eastern Slovakia & 19 \\
\hline Number of Districts & 26 & 23 & 37352 & districts \\
\hline Average no. of Inhabitants & 43998 & 24585 & 0,7636 & $\mathbf{0 , 7 4 6 2}$ \\
\hline $\begin{array}{l}\text { Share of income tax of in- } \\
\text { dividual persons on tax } \\
\text { revenues of districts }\end{array}$ & 0,6761 & 0,8152 & & \\
\hline
\end{tabular}

Source: Authors' own data processing.

In the district towns of Eastern Slovakia, shared taxes represent a significant share in tax revenues, in other words this tax constitutes the bulk of their tax revenues. Conversely, the smallest share (below 0.65) was achieved by the district towns of Western Slovakia (Bratislava (1), Senec (48), Senica (49), Galanta (12), Púchov (41)). Also, the calculated total average for all years and all monitored district towns reached a high final value of $0.75(75 \%)$. Only $25 \%$ of the city's total tax revenues were gathered by collecting local taxes and fees. Although individual income tax under our current legislation is included in the income of local government units, it is essential that cities/municipalities pay more attention to the strengthening of local tax and fee collection. The content analysis of the final accounts of the monitored cities revealed that several of them experience a challenge to ensure their collection, which is often associated with a high backlog in these type of taxes.

The second criterion for the redistribution of individual income tax is the number of inhabitants recalculated by the coefficient depending on the inclusion of the municipality in the size category. This criterion has a weight of $32 \%$. The coefficients for individual size categories of municipalities reach values from 0.89 (municipalities up to 1,000 inhabitants) up to 2.35 for the capital. The difference in the value of the coefficient between the smallest towns and the big cities, up to 50,000 places, is only 0.05 . The number of inhabitants is determined by the number of inhabitants of the municipality with permanent residence in the municipality on 1 January of the previous calendar year.

Table 3

The yield of share tax per capita for district towns of SR

\begin{tabular}{|c|c|c|c|c|}
\hline & \multicolumn{3}{|c|}{ AVERAGE VALUES FOR YEARS 2013-2017 } & \multirow{4}{*}{$\begin{array}{c}\text { Average } \\
\text { values } \\
\text { for all } \\
\text { monitored } \\
\text { districts }\end{array}$} \\
\hline & Western Slovakia & Central Slovakia & Eastern Slovakia & \\
\hline Number of Districts & 26 & 23 & 19 & \\
\hline Average no. of Inhabitants & 43998 & 24585 & 37352 & \\
\hline $\begin{array}{l}\text { The yield of share tax per } \\
\text { capita for districts }\end{array}$ & 275,38 & 235,62 & 296,97 & 288,84 \\
\hline
\end{tabular}

Source: Authors' own data processing. 
The average total value for all district cities was 289 EUR per capita. Approximately 30 district cities did not exceed the above average value. Significantly high performance in this indicator was achieved by Námestovo (30), with a total of 449 EUR of share tax per capita. Such a high proportion can be justified by the first criterion of the redistribution of income tax revenue according to which the altitude of the city is also taken into account. In the case of this city, the coefficient of altitude is 1.3960 (e.g. compared to the capital Bratislava (1), which is located on the lowland and with a coefficient set at 0.8179 ).

The third criterion is the number of pupils in schools and education centres. The number of pupils and school facilities is determined according to a special regulation and calculated by the relevant coefficient. It is a criterion with a maximum weight of 40\%. As of 1 September 2017, municipal taxation on the activities of the school children's club has been divided on the basis of the number of children admitted, the criteria being those from zero to fifth grade of elementary school who represent the largest group attending the club. For this reason, the value of the coefficient was changed for children of the club, for which the financial funds are distributed from the original value of 1.6 to 6.0 (The Explanatory Memorandum, 2017). The amendment to the regulation brought an adjustment of the coefficients for a child in a childcare centre, in the founding competence of a municipality with no more than 25 children, so that with the decreasing number of children in the childcare centre, the amount of allocated financial funds per child also increases in a more even manner. Changing the coefficient values did not change the amount of funds for childcare centre criterion.

The fourth criterion is the number of inhabitants in the municipality who have reached the age of 62 and with permanent residence in the municipality as of 1 January of the previous year. This criterion has a weight of $5 \%$. The introduction of this criterion takes into account the increased demands on municipalities to finance competences in the area of social services for pensioners, for whom municipalities provide nursing services or provide care in social service facilities established by the municipalities. Since no coefficient is used to redistribute revenue between municipalities, it is the application of the principle of equality - individual municipalities receive the same amount of tax income per capita. However, this coefficient does not take into account different service costs in the individual regions of the country. This favours the provision of services in economically weaker regions, another element of solidarity and financial balancing.

Financial self-sufficiency in self-government is one of the general indicators reflecting a degree of autonomy and stability of the local government management (Horváthová, 2009). It helps to monitor the level of financial autonomy and its development. Although this indicator cannot capture the complexity of financial autonomy, it provides an idea of the financial position of local territorial self-government.

The Act on Budgetary Rules of Territory (Section 5 (1) of Act No. 583/2004 Coll.) includes in this category items - tax revenues (sub-items: revenue from shared tax, taxes on goods and services, real estate tax, municipal waste fee and small construction waste and local development fee) and non-tax revenue (sub- 
items: business income and property ownership, administrative and other fees, interest on deposits and loans, and other non-tax revenue). The shared tax is thus classified as their own income. However, this definition is quite inconsistent for various reasons. The aspect of the purpose of using one's own revenue to finance one's own original competences gives some entitlement to its inclusion in the category of their own income. On the other hand, municipalities cannot realistically influence the construction of their overall amount or the method of division.

\section{Figure 1: The measure of financial self-sufficiency} of district cities in Slovakia

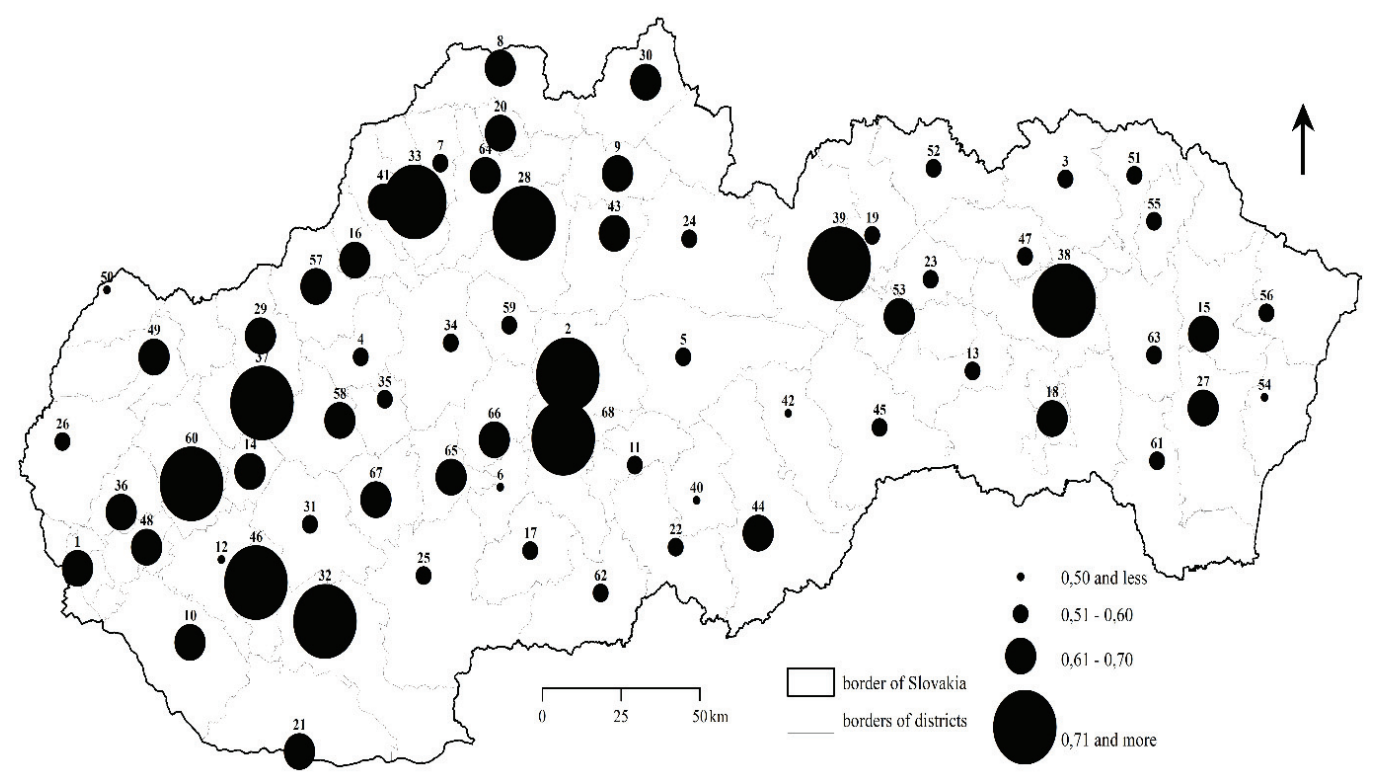

Source: Authors' own data processing.

Numbers of district cities: 1-Bratislava, 2- Banská Bystrica, 3- Bardejov, 4- Bánovce nad Bebravou, 5- Brezno, 6- Banská Štiavnica, 7- Bytča, 8- Čadca, 9- Dolný Kubín, 10- Dunajská Streda, 11- Detva, 12- Galanta, 13- Gelnica, 14- Hlohovec, 15- Humenné, 16- Ilava, 17- Krupina, 18- Košice, 19- Kežmarok, 20- Kysucké Nové Mesto, 21- Komárno, 22- Lučenec, 23- Levoča, 24-Liptovský Mikuláš, 25- Levice, 26- Malacky, 27- Michalovce, 28- Martin, 29- Nové Mesto nad Váhom, 30- Námestovo, 31- Nitra, 32- Nové Zámky, 33- Považská Bystrica, 34- Prievidza, 35- Partizánske, 36- Pezinok, 37- Pieštany, 38- Prešov, 39- Poprad, 40- Poltár, 41- Púchov, 42- Revúca, 43- Ružomberok, 44- Rimavská Sobota, 45- Rožňava, 46- Šala, 47- Sabinov, 48- Senec, 49- Senica, 50- Skalica, 51- Svidník, 52- Stará Lubovňa, 53- Spišská Nová Ves, 54- Sobrance, 55- Stropkov, 56- Snina, 57- Trenčín, 58- Topolčany, 59- Turčianske Teplice, 60- Trnava, 61- Trebišov, 62- Velký Krtíšs, 63- Vranov nad Toplou, 64- Žilina, 65- Žarnovica, 66- Žiar nad Hronom, 67- Zlaté Moravce, 68- Zvolen 
The results of the analysis show that it is possible to evaluate positively that only five district cities achieved low results at 0.50 and below (Sobrance (54), Rožňava (45), Poltár (40), Galanta (12), Banská Štiavnica (6 ), Skalica (50)). The total average value for all cities surveyed and for all reference years was 0.61 . This result shows that district cities in Slovakia are on average $61 \%$ able to secure their own income, while the remaining 39\% are from foreign sources (mainly subsidies). Above-average values exceeded more than half of the district cities, especially Western and Central Slovakia. The lowest level of financial self-sufficiency is achieved by district towns in Eastern Slovakia. The greatest financial self-sufficiency was achieved mainly by the largest Slovak cities, such as Prešov (0.71), Banská Bystrica (0.73), Trnava (0.74), Martin (0.70), and Poprad (0.71), while Slovakia's two largest cities, Bratislava (0.69) and Košice (0.60), achieved surprisingly low financial self-sufficiency. A significance of this indicator lies in the expression of the independence of transfer points from the central government level even though the tax revenue is shared tax that is actually redistributed to the cities according to the applicable criteria. This indicator does not take into account the degree of tax jurisdiction beyond the powers of the cities. Its assessment over time reveals an uneven growth of GDP in individual regions of Slovakia and the related problems of municipal finances. Because economic conditions are subject to the process of change, the self-sufficiency of local governments needs to be reassessed.

\section{Conclusion}

A new system of financial compensation in the SR is based on the redistribution of individual income tax using a formula containing criteria corresponding to the type and volume of competences that the local government performs. In this paper, we tried to evaluate the impact of changes on tax revenues of municipalities. The analysis shows that the shared tax forms the highest proportion of the tax revenues of district towns in Eastern Slovakia. The financial self-sufficiency indicator reaches the highest values in the most economically advanced part of the country, where district cities have a larger population due to better employment opportunities and low unemployment rates. Therefore, it seems necessary to adjust the mechanism of financial equalisation due to changes in the demographic structure and due to the need to focus more on the tasks of supporting the development of cities and municipalities, thus reducing the differences in the scope and quality of public goods provision.

An ongoing process of globalisation, the transition from an industrial society to an information society, as well as the process of deepening European integration and the strengthening of its bodies' influence at the expense of national governments, are seeing permanent discussion on the position of central government vs. local governments. In different types of states, there are different approaches to dividing tasks between central and local governments. Urban development and its effective management has long been a very serious issue, from the regional as well as the national and international perspectives. 
The article was compiled with the support of the Scientific Grant Agency of the Ministry of Education, Science, Research and Sport of the Slovak Republic no. VEGA 1/0153/18: Evaluation of Regional Self-Government Performance in the Context of its Impact on Economic and Social Factors of Regional Development in the Slovak Republic.

\section{REFERENCES}

1. Bird, R.M. (2003). Local and Regional Revenues: Realities and Prospects. Perspectives on Fiscal Federalism. Washington: World Bank, 2003. Available at: https://worldbank.org/publicsector/decentalization/bird2003.

2. Boadway, R. (2004). The Theory and Practice of Equalisation. CESifo Economic Studies, 2004, vol. 50 no 1, pp. 211-255.

3. Čavojec, J. \& Sloboda, D. (2005). Fiškálna Decentralizácia a Obce. M.R. Štefánik The Conservative Institute. Bratislava.

4. Daňková, A., Čepelová, A. \& Koreňová, D. (2017). Process Efficiency of Local Self-Government in Slovak Republic. Journal of International Studies, vol. 10, no 2, pp. 309-317.

5. Ermini, B. (2009). Decentralization, Local Government Reform and Local Government Performance. The Impact of Inter-Communality. Working Paper, no 633, Pavia: Società Italiana di Economia Publica. Available at: http://www.siepweb.it/siep/images/joomd/1401049999633.pdf (accessed: 12 August, 2019).

6. Horváthová, L. (2009). The Development of Financial Self-Sufficiency of Cities and Municipalities of SR in the Context of Fiscal Decentralisation. In: National and Regional Economics VIII. Košice, Technická univerzita, Ekonomická fakulta, pp. 245-256.

7. Chapman, J.I. (2003). Local Government Autonomy and Fiscal Stress: The Case of California Counties. State \& Local Government Review, vol. 35, no 1, pp. 15-25.

8. Jílek, M. (2008). Fiskální Decentralizace, Teorie a Empirie. Praha: Wolters Kluwer.

9. Johnson, R., W. \& Minis, Jr. H.P. (1996). Toward Democratic Decentralisation: Approaches to Promoting Good Governance. Research Triangle Institute. Available at: http://rti.org/pubs/ Toward_demo_decen.pdf (accessed: 12 August, 2019).

10. Kadeřábková, J. \& Peková, J. (2012) Územní Samospráva - Udržitelný Rozvoj a Finance. Praha: Wolters Kluwer. 
11. Maruchnič, J. \& Čunderlík, L. (2007). The Fiscal Decentralisation in Slovakia. International and Comparative Legal Review, vol. 5, no 14, pp. 64-72.

12. Nižňanský, V. \& Hamalová, M. (2013). Decentralizácia a Slovensko. Bratislava: Vysoká škola ekonómie a manažmentu verejnej správy.

13. Sungurov, A.Yu. \& Tiniakov, D.K. (2018). Russian Administrative Reform: Better Outcomes through Broader Participation. Public Administration Issues, Special Issue. (Electronic edition), pp. 133-144 (in English). Available at: DOI: 10.17323/1999-5431-2018-0-5-133-144 (accessed: 12 August, 2019).

14. Youngman, J.A. (2016). Good Tax.Legal and Policy. Issues for the Property. Tax in the United States. Cambridge, Massachusetts, Lincoln Institute of Land Policy.

\section{OFFICIAL DOCUMENTS}

1. The Complete version of the government regulation 668 of the Slovak Republic from 1st December 2004 on the distribution of income tax on territorial self-government in the wording no. 519/2006 Coll., No. 623/2007 Coll., No. 412/2008 Coll., No. No. 276/2010 Coll., No. 531/2010 Coll., No. 415/2012 Coll., No. 417/2014 Coll., No. 370/2016 Coll. and no. 356/2017 Coll.

2. The Explanatory Memorandum to the Government Order no. 356/2017 p The Distribution of the Income Tax Revenue to Territorial Self-Government, as amended.

3. Act no. 583/2004 Coll. on The Budgetary Rules of Territorial Self-Government.

4. Final Accounts of District Cities 2013-2017. 